\title{
MARKETING CHALLENGES FOR SOUTH AFRICAN PUBLIC SECTOR BUSINESS INCUBATOR
}

\author{
- Donaldson Walter James, Pauceanu Alexandrina Maria
}

\begin{abstract}
Entrepreneurship and innovation form the cornerstone of economic development in many developing countries. Through this, rather ideal combination employment can be enhanced, communities can be uplifted through education, and growth can be increased through discretionary purchasing power. This cycle has positive spinoffs which can alleviate poverty and decrease famine. Recent local research suggests that more than eighty percent of entrepreneurs, start-ups and Business 'Incubatees' don't make it through their first year of establishment after leaving a Business Incubator programme. This paper tries to identify some of the marketing challenges faced by Business Incubators, and indeed BIMs in the Public Sector environment in South Africa. Identification and highlighting the possible drawbacks for 'incubatees' may assist them with success or meeting competitive challenges when they depart from the security of the relevant programmes. This study examines some of the skills, knowledge and attributes required for BIMs in this sector and what is required to meet the business and marketing challenges faced to remain sustainable. The survey was aimed at the largest, focused segment of South African Business Incubators affiliated to the industrial public sector and the hypothesis was to prove that strategic marketing information, acumen and knowledge is a key differentiator towards the growth and sustainability of Business Incubators in that sector. It is notable that these marketing challenges may also compare favourably with several other public sector segments in relevant countries of the southern African region as similar macroeconomic challenges are faced.
\end{abstract}

Keywords: business incubators, economic development, entrepreneurship, sustainability

JEL Classification: M39, L26

\section{INTRODUCTION}

South Africa, an emerging economic market, has gone through numerous macro and socioeconomic challenges for many years by now. As a young democracy, it was propelled upwards under the ANC government and the leadership of Nelson Mandela. However, between 1994 and 2012, the population had increased by $27 \%$ whilst employment had grown only by $7 \%$ (SARB bulletin - March 2013).

According to the South African statistical agency (STATSSA), the unemployment had also gone up from $22.9 \%$ in 1994 to $25.1 \%$ in 2012 and now sits on a percentage of more than $27.7 \%$ in the first quarter of 2017. This does not include statistics in the huge informal sector and the citizens who have stopped looking for work as such. 
The 'radical economic transformation' - a challenging plan with the growth target of above 5\% by 2030 and "five million new jobs from 2010 to 2020 " became only a pipedream. In fact, South Africa is losing jobs at quite an alarming rate with an additional "net quarterly decrease of 48000 employees between December 2016 and March 2017”.

Work and education, according to the World Economic Forum, impact on the lives of nearly one billion people in the Sub-Saharan region with $60 \%$ of its population categorised as youth (under 25 years old) while the region is set to increase from 370 million in the working-age sector to 600 million by 2030. South Africa is being expected to contribute significantly to the growth and development of this region, mainly through Information, Communications and Technology (ICT) sector's capacities and development.

\section{THEORETICAL BACKGROUND}

One of the key initiative ways to kickstart any sluggish economy is through the role of entrepreneurs (Leidholm and Mead, 2013). Entrepreneurs are viewed as key contributors to building communities and providing jobs, generating income and revenue streams within many poor regions. (Masutha, 2013; Belás et al., 2015; Ključnikov et al., 2016; Kozubíková et al., 2017; Dobeš et al.,2017; Androniceanu, 2017) researched that more than 80\% of start-ups, ranging from independent entrepreneurs, micro, small, medium, micro enterprises (SMMEs) fail to make it through the first year of existence. Koisova et al. (2017) states, that government creates administrative barriers for entrepreneurs very often. However, the South African government decided that the best way to stimulate the sluggish economy was by training and supporting local entrepreneurs.

According to the National Business Incubator Association (NBIA), formed in the Mid-western area of the United States in 1950's, a Business Incubator is 'a business support process that helps fast track start-up and fledgling companies during an initial 'incubation' stage'. This period may last in the region for three years which will 'protect' them from huge expenses and hopefully, competitiveness in the industry. It gives small companies the opportunity to grow and develop in a secure environment whilst learning strategic marketing and business skills.

For an entrepreneur to gain acceptance and possible entrance into a Business Incubator, the entrepreneur needs to meet several criteria such as a carefully designed Business Plan with a comprehensive Marketing through intensive market research. This will give the BIM the insight to assess and appraise the 'incubatee' through a strict set of criteria which will further enable the BIM to see if there is a strategic 'fit' with the Incubator and incubatee and if that fit will show sustainability within the BI. More importantly, the BIM needs to determine if the incubatee will be successful once they have graduated from the Incubator to face the more competitive world beyond.

Once the entrepreneur or start-up is accepted into the business incubator, they are provided with ongoing assistance in business support services during the tenure within the incubation period. This should alleviate costs, offer training and market knowledge to all incubatees in a collaborative way. It is essential to have all the necessary 'value add' to give the incubatees the best chance of sustainability and survival according to Al-Mubaraki and Busler, (2011b), Anderson and Al-Mubaraki (2012) and Lauzikas et al. (2017). 
Not all Business Incubators offer the same business support services according to Bayhan (2001), so it is necessary for the BIM to analyse and assess the best support services that will provide success within and to the incubator considering the stakeholders' involvement in the relevant incubator.

BIs are the mainstay of economic development programs by combining the entrepreneurial drive of a start-up with available resources to enhance 'value' (Salem, 2014). It is important, therefore, to make all the necessary services available to encourage support and transition through this tenure. Chan \& Lau (2005) and Grimaldi \& Grandi (2005) all agree that whilst the Business Incubator offers the necessary Business Support Services to the Business Incubatees, constant communication and collaboration is critical with the BIMs. Moreover, the BIMs need to have constant stakeholder involvement and engagement to ascertain what is happening in the uncontrollable macro environment and controllable microenvironment that will undoubtedly affect the success of their Business Incubator.

Technology based start-ups require ongoing innovation, creativity and design and entrepreneurship. This will involve critical thinking and collaboration within eco-systems. The fast-paced world of today necessitates flexible innovation and speed to market. Therefore, it is important that BIMs are strategic thinkers linking the innovative products made within the incubator to identified key markets outside by way of various marketing channels that can take the products to market and consumers seamlessly and profitably.

Through the evolution of Business Incubators since its inception towards the end of the late 1950's it has become evident that incubators have to be more 'competitive'; more sustainable; more robust so that as markets change, BIMs and their incubators can become more flexible, innovative and creative to challenge the dynamic enterprise forces that exist within their industries or environments. Lalkaka and Bishop (1996) identified that there was more to managing business incubators than just physical and financial resources whilst Lai \& Lin (2015) allude that Business Incubators face similar problems that normal businesses may encounter. These could include lack of vision, failure to define specific strategic goals, misinterpretation or identification of target markets, or poor stakeholder relations.

Du Toit and Sewdass (2014) emphasise that the economic success of a country depends on the balance of import and export of goods. By producing much needed materials of high quality should assist a country to prosper, gain critical mass and attain a competitive advantage in that industry. Furthermore, they suggest that it is important to research and build up business intelligence at a macro-economic level which may ensure success. (Androniceanu, Ohanyan, 2016). As pointed out by Waheeduzzaman (2002), competitive advantage should encourage an improvement in the standard of living for citizens in that country.

The growth of Business Incubators in the first world 'Developed' economies has been steady over a period of time since inception but reached a peak in the early 2000s. This may have been due to various macro-economic issues as well as strong competition within various global entities, higher cost of production and seeking to maintain shareholder value. Global companies' competitiveness has forced many enterprises to seek new markets throughout the world whilst researching for and finding low cost countries that may meet their standards in raw materials and production outside Europe and a 'westernised' world (Fig 1). 


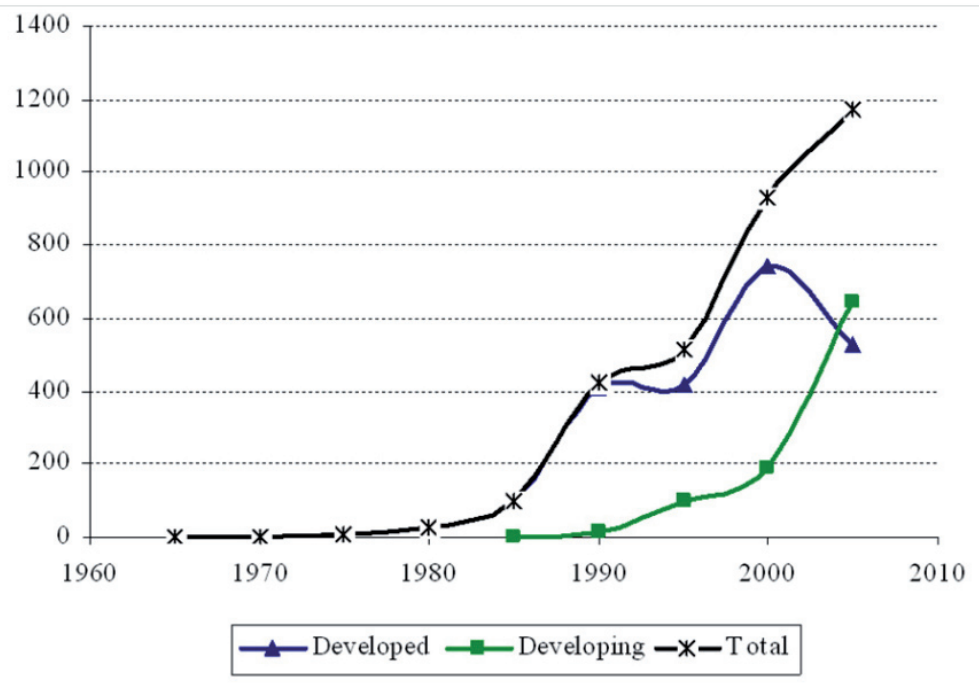

Fig. 1 - Growth comparisons in business Incubators. Source: Akcomak (2009).

However, growth is steadily increasing in 'Developing' countries through the increasing of skills and development in education, technical ability and the ease with which many developing countries are open to negotiation on various business opportunities. As Figure 1 shows, the Business Incubators in the Developing word has now surpassed that of the developed world. Reasons for this may be that global companies have now identified global markets and are assisting in the developing of business incubators through a PPP (Public Private Partnership) or Helix type model with other governments, universities and Business Incubator units (Mishenina et al., 2017).

Comparative studies by InfoDev (2009), Masutha (2013) and Kot et al. (2016) conclude that South Africa has one of the world's highest failure rates in terms of first-year business and entrepreneurs, start-ups and SMMEs are struggling to fill the void left by the casualties.

To counteract these challenges, the South African government are trying to focus this on youth entrepreneurship as a possible solution to increase economic development. This has been met with scepticism as the economic issues and challenges facing South Africa are a far cry from many other 'developing' and indeed 'developed' worlds. Years of Apartheid have left South Afri$\mathrm{ca}$ in a desperate and divided country filled with anger, bitterness in some places, racism, cultural tendencies and underprivileged communities. The education gap is wide and many generations of potential entrepreneurs have struggled, needing guidance, coaching, mentoring in business principles. Furthermore, many 'incubatees' toil with business acumen even after leaving the Business Incubator.

Therefore, it was realised that the BIM; sometimes known as the 'centre manager' would need to be more strategic in thought and less operational in work. It is critical for BIMs to know how incubatees (start-ups, entrepreneurs, SMMEs) within and potentials wanting to enter the incubator are doing with their products and/or services and how each of these incubatees impact on each other and the external competition beyond the incubator. 
Al-Mubaraki \& Busler (2010) and Lai \& Lin (2015) allude that Business Incubators face similar problems that normal businesses may encounter. These could include lack of vision, failure to define specific strategic goals, misinterpretation or identification of target markets, or poor stakeholder relations. Bruneel et al (2012) emphasise that whilst private business incubators are almost exclusively profit driven, mainly by venture capitalists, angel investors and private funders wanting a healthy return on their investment, public business incubators are also required to be 'competitive' in trying to sustain a venture. The objectives are usually quite different in that they are normally focused on job creation to alleviate poverty and unemployment, it is imperative that they work diligently with their objectives. Not doing so will be detrimental to the existence of the incubator.

Chandra (2009); InfoDev (2010a); Al-Mubaraki and Busler (2011a); Sandheep and Wolfgang (2011) all allude that Business Incubator's main goal is to grow businesses through incubation programmes which will encourage financial viability, sustainability and independence but as Fini et al (2012) emphasise, the F and key staff compliment require good skills, knowledge and attitude to drive the business coupled with strategic marketing management insight to grow and sustain it whilst Timm (2012) concur that South Africa seems to be falling behind some other developing countries as far as growth of Business Incubators is concerned therefore, to strengthen their 'value propositions' in various regions and becoming more visual, it is essential for BI Managers to market their incubator products and services more aggressively in a competitive and hostile environment.

\section{RESEARCH OBJECTIVE AND METHODOLOGY}

In the Literature Review, it was becoming more apparent that the concept of Business Incubators was increasing in the developing world (Fig. 2). Furthermore, there was a greater need for skills, knowledge and attitude from the key decision-makers, notably the BIMs to have a more polished understanding of the incubatee's needs, their products and services that are being made and sold outside the incubators, and the customers who are likely to buy their products. As suggested by (Al-Murbaraki \& Busler 2011a) et al., competitive advantage was the key focus in sustaining Business Incubators keeping them financially viable and eventually independent.

Business Incubators have been identified to stimulate developing economies and creating employment for its citizens. In doing so, this should add to the Gross Domestic Product (GDP) of the country. This requires goods manufactured and sold to communities and other markets at a profit which will grow the steady income to assist households. The criteria then are for Business Incubators and their management team to be able to manage the incubator, nurture and guide their incubatees through their tenure within the incubator, giving them the business knowledge and skills to perform both within the incubator and when they leave the program to face the external competition on their own independence.

A survey was performed in August and September 2016, qualitative in nature to determine the marketing and business skills and knowledge required by the BIMs to sustain the Business Incubator, strengthen its resistance to other competitive and marketing forces and grow its marketing and brand awareness to its internal and external stakeholders. The survey was aimed at the BIMs 
of the largest, focused segment of South African Business Incubators affiliated to a public sector economic development agency. Whilst the cross-sectional study was completed due to time constraints, a longitudinal study may be completed later.

The hypothesis was then to prove that strategic marketing information, acumen and knowledge is a key differentiator towards the growth and sustainability of local public sector Business Incubators in South Africa. Without this skill from a BIM and the key personnel of Business Development or Marketing Manager affiliated to the incubator, there is a strong possibility that relevant business incubators will not grow. Moreover, the BI's 'incubatees'; the small and medium enterprises that depend on the BI's for business intelligence, marketing knowledge, business support and prowess, will not prosper and grow once they graduate from the incubator.

The data collected was that of Qualitative or Mixed from the both open and closed questions raised. This approach was taken to carefully analyse and compile the responses given by the respondents, in this case the BIM.

The researcher contacted top management of the economic development agency for approval to approach the respondents in this project. The Programme comprised 40 business incubators and all respondents were contact via telephone and e-mail on several occasions. The compilation of completion of questionnaires was a challenge and difficult to get contact time with the respondents. Telephonic appointments had to be set up as alternative arrangements if the responses where not completed via mail. It was necessary to travel to a few of the Business Incubators to meet the BIMs, as their time was limited on some occasions. Thirty-five (88\%) said that they would complete the survey but due to their heavy work schedule and tight deadline factor, some did not complete the questionnaire satisfactorily so their responses were eliminated from the analysis. The sample size of 22 respondents represent $55 \%$ of the segment population.

For descriptive analysis, the sample size calculation is based on the estimation of proportions (e.g., the proportion of respondents who rated an item as very important). Based on worst-case (for sample size) estimates of $50 \%, 5 \%$ precision and the $95 \%$ confidence level, and a population size of 45 , a sample size of 41 would be required. The actual sample size of 22 corresponds to a precision of $14.9 \%$ (rather than $5.0 \%$ ).

For the comparison of scores (marketing vs non-marketing), in Figure 3... a paired-sample t-test is used. Based on the detection of a medium effect size (should it exist), $80 \%$ power, and a 5\% significance level, a sample size of 34 is required. An actual sample size of 22 means that only larger effect sizes can be detected.

For the correlation of items between items in Figure 4, a Spearman's rank order correlation was used. The analysis stemming from Figure 2 and the subsequent four hypotheses, Wilcoxon rank sum tests were performed.

\section{RESULTS AND DISCUSSION}

A series of questions were grouped to identify the three main challenges that the Business Incubator faced and how it was possible, in the view of the Business Incubator/Centre Manager, to eliminate or meet those challenges. It was clear that there were various reasons for the growth 
and/or decline in the business incubators. Many reasons where of a political and socio-economic nature including government policy, funding and 'red tape' (Table 1). What was more alarming was the lack of marketing-related challenges such as 'lack of marketing strategy', 'identification of customers' from a poor customer database, access to markets and the strategic planning to access those markets.

It was also realised that there was not an integrated marketing communication strategy put in place between all key strategic stakeholders such as main sponsor, BIM and key staff; and of course other key donors and contributors. It seemed that Business Incubators were expected to implement a series of steps in line with Economic and Socio-economic policy but were not given the full support needed to be successful in driving strategic planning with through a concerted marketing-oriented approach. Thus when development and sales hit a low ebb, most BIMs are at a loss as what to do or how to manage the situation. The dynamic macro-economic situation is constantly changing and therefore industries need to be aware of this so that they can adjust and constantly meet the needs of the identified target markets. (Table 1).

Tab. 1 - Knowledge of Industry Dynamics. Source: own compilation.

\begin{tabular}{|r|l|}
\hline Q & Name three reasons that attribute to the growth/decline? \\
\hline $\boldsymbol{~}$ & $\begin{array}{l}\text { Market/marketing-related reasons including lack of marketing strategy, Poor customer } \\
\text { base, lack of marketing initiatives, lack of market access, }\end{array}$ \\
\hline $\boldsymbol{r}$ & $\begin{array}{l}\text { Lack of funding including poor economic conditions and recession and investor confi- } \\
\text { dence. }\end{array}$ \\
\hline - & Lack of skilled staff including poor selection of incubatees. \\
\hline Q & Three main challenges for your Business Incubator currently? \\
\hline - & Funding. \\
\hline - & Government policy and red tape. \\
\hline - & Access to market. \\
\hline Q & What is needed to alleviate current challenges? \\
\hline - & $\begin{array}{l}\text { Source more funding, marketing-related issues, reviewing government policy, more } \\
\text { SEDA involvement and Internal Issues }\end{array}$ \\
\hline
\end{tabular}

The respondents were then asked to rate the skills required as a BIM to meet the objectives of their own Business Incubator. The graph below shows, for each of the ten items, the percentage of respondents who rated the item as important (a rating of 6 or 7 on the 7 -point scale). The items are presented in order of decreasing importance.

- Solid business management skills and Vision to sustain the BI were rated most highly; and

- Entrepreneur/VC specialisation, all-round marketing skills, and local admin and support, were rated the lowest. 
(c) Solid Business Management skills (e) Vision to sustain Business Incubator (a) Thorough knowledge of BI work and experience (j) Identification of customers and potential customers (g) Identification of stakeholder (h) Knowledge of local industry climate and culture (f) Financial aspects of BI and industry funding

(b) Entrepreneur or Venture Creation specialist (d) All round marketing skills (i) Local administration and support

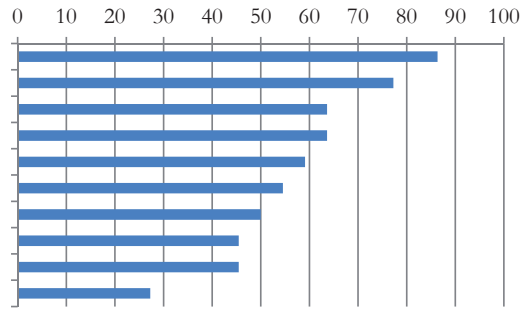

Fig. 2 - BI Managers perception of skills set required. Source: authors

Next, composite scores at respondent level were created for marketing items (items b, d, g, h, j) and non-marketing items (all other items) by averaging the responses for the given items. The median Marketing score was 5.6 (interquartile range (IQR) 5.2-6.2; range 4.0-7.0). The distribution of the data is shown below. Marketing and Non-marketing scores were compared. There was no significant difference between the Marketing and Non-Marketing scores (paired t-test; $\mathrm{p}=0.11$ ). Thus, neither set of items was scored higher (or lower) in importance than the other set.

Tab. 2 - BI Managers Marketing and non-Marketing own skills set scores compared. Source: authors.

\begin{tabular}{|c|l|c|c|c|c|c|c|c|c|}
\hline Variable & \multicolumn{1}{|c|}{ Label } & N & Mean & $\begin{array}{c}\text { Std } \\
\text { Dev }\end{array}$ & Median & \multicolumn{2}{|c|}{ IQR } & $\begin{array}{c}\text { Mini- } \\
\text { mum }\end{array}$ & $\begin{array}{c}\text { Maxi- } \\
\text { mum }\end{array}$ \\
\hline _13_Mkt & Marketing score & 22 & 5.6 & 0.8 & 5.6 & 5.2 & 6.2 & 4.0 & 7.0 \\
\hline _13_NMkt & $\begin{array}{l}\text { Non-marketing } \\
\text { score }\end{array}$ & 22 & 5.9 & 0.7 & 6.0 & 5.4 & 6.4 & 4.2 & 7.0 \\
\hline
\end{tabular}

The graph below shows, for each of the ten items, the percentage of respondents who rated the item as important (a rating of 6 or 7 on the 7-point scale). The items are presented in order of decreasing importance.

Again, it is noted that:

- Grasp of BD and marketing, identification and attraction of customers, and identification of customers and potential customers, were rated most highly; and

- Local admin and support was rated the lowest.

Next, composite scores at respondent level were created for marketing items (items 2,4,7,8,10) and non-marketing items (all other items) by averaging the responses for the given items. 


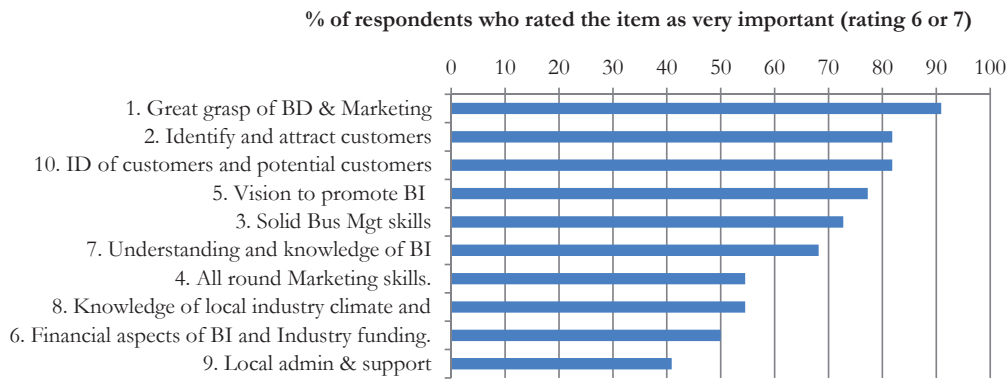

Fig. 3 - BI Managers perception of skills set required for role of BD/Marketing Manager. Source: authors.

The median Marketing score was 6.0 (interquartile range (IQR) 5.4-6.6; range 4.8-7.0). The distribution of the data is shown below. We see that both scores are negatively skewed; responses are predominantly towards the 'important' end of the rating scale.

Finally, the marketing and Non-marketing scores were compared. There was no significant difference between the Marketing and Non-Marketing scores (paired t-test; $\mathrm{p}=0.70$ ). Thus, neither set of items was scored higher (or lower) in importance than the other set indicating that marketing was not a prominent feature in the growth and sustainability of Business Incubators.

Tab. 3 - BI Managers Marketing and non-Marketing scores for Marketing Manager compared. Source: authors.

\begin{tabular}{|l|l|l|l|l|l|l|l|l|l|}
\hline Variable & Label & N & Mean & Std Dev & Median & \multicolumn{2}{l|}{ IQR } & $\begin{array}{l}\text { Mini- } \\
\text { mum }\end{array}$ & $\begin{array}{l}\text { Maxi- } \\
\text { mum }\end{array}$ \\
\hline _16_Mkt & $\begin{array}{l}\text { Marketing } \\
\text { score }\end{array}$ & 22 & 5.9 & 0.6 & 6.0 & 5.4 & 6.6 & 4.8 & 7.0 \\
\hline _16_NMkt & $\begin{array}{l}\text { Non-market- } \\
\text { ing score }\end{array}$ & 22 & 5.9 & 0.7 & 6.0 & 5.4 & 6.4 & 4.4 & 7.0 \\
\hline
\end{tabular}

The scatterplot below shows the relationship between the 9 comparable items from the perceived roles of the BIM and the BDO/Marketing Manager. The metric displayed is, for each item, the percentage of respondents who rated the item as important (a rating of 6 or 7 on the 7-point scale).

The correlation between the two sets of items was positive and significant (Spearman's rho $=0.82$; $\mathrm{p}=0.0072$ ). Thus, items rated highly in similar questions regarding various roles were also rated highly, and vice versa. In effect, this means that both sets of values were important for the BI Manager and the BDO/Marketing Manager skills set.

In previous questions, respondents also remarked on challenges with the main sponsor's programme citing an overburden of monthly reports, having to rely so much on the main funder and its funds. Building a 'centre of excellence' was a key initiative for some respondents. 


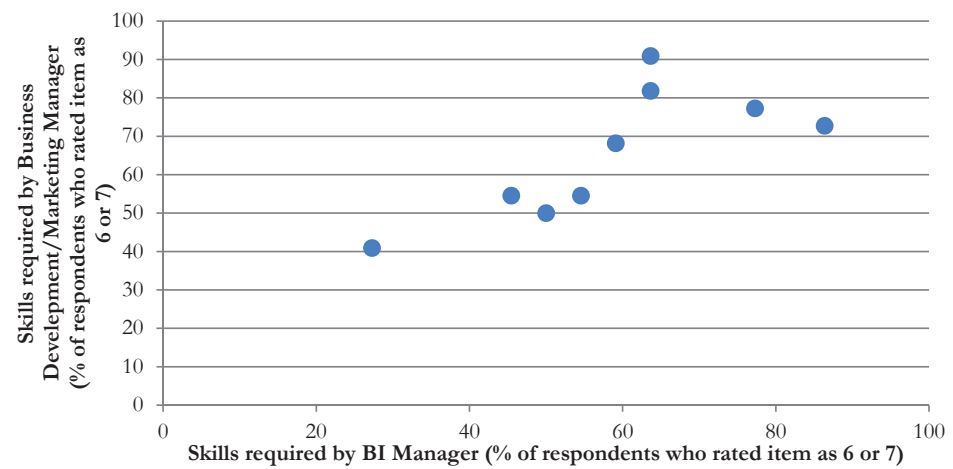

Fig. 4 - Correlation between comparable variables from BIM and BDO/Marketing Manager roles. Source: authors.

Another question required the respondents to rate the main funder in a Likert scale on various comments. The statements were developed in line with the organisation's mission, vision and objectives from their recent Annual Report. The ratings given are not in line with funder's objective to "provide business-related information, advice, consultancy, training and mentoring services in all areas of enterprise development".

The graph below shows, for each of the 9 items categorised, the percentage of respondents who rated the item as very good/excellent (a rating of 6 or 7 on the 7-point scale). The items are presented in order of decreasing rating.

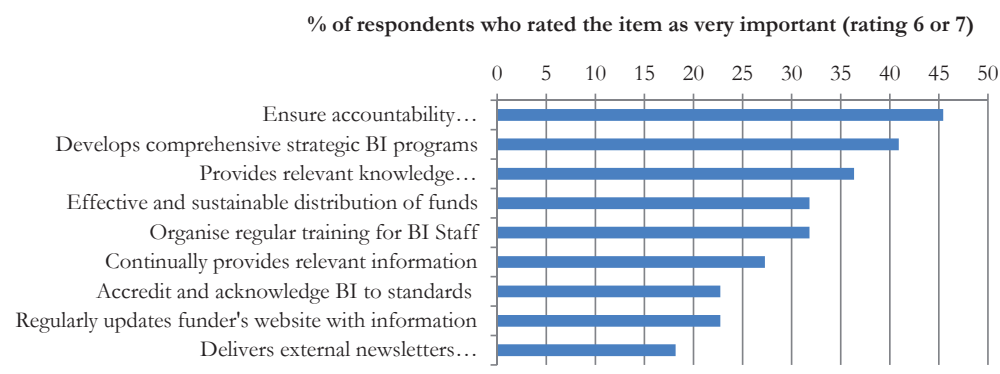

Fig. 5 - Important ratings of main sponsor. Source: authors.

It is observed that none of the items were rated particularly highly; all items scored less than $50 \%$ very good/excellent ratings. In conclusion:

- Ensuring accountability was rated most highly; and

- Accreditation of the BI, updating of the website, and newsletters, were rated the lowest.

Figure 6 shows the 'gaps' between was is 'expected' on a top rating of 7 and an 'actual' or delivered reading from the Business Incubators. In the survey, the respondents were requested to 
name their three key staff members, with their main qualifications and the number of years' experience in that position. $82 \%$ of the respondents named the BIM or Centre Manager in number one position.

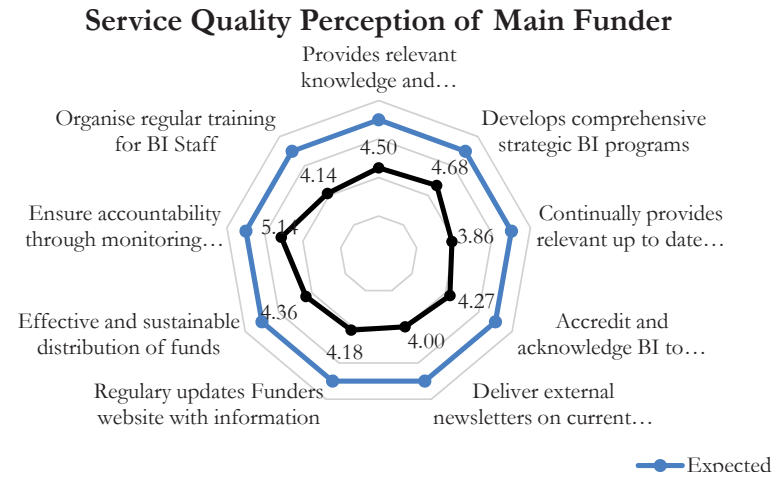

Fig. 6 - Service Quality Perception of Main Funder. Source: authors.

A list of various regular services identified by National Business Incubator Association (NBIA) in the United States, Centre for Strategy \& Evaluation Services (CSES) in the United Kingdom and InfoDev, part of the World Bank, as key to Business Support were asked to be rated by the BIM's. The services for each incubator were rated on a 1 to 7 scale. As the Business Incubators belonged to various industrial sectors, it was shown that the importance varied from incubator to incubator depending on client's relevant needs. The average ratings were accumulated in the specific services of each of six main sectors of Administrative services, Information Technology, Financial, Human Resources, Strategic Marketing and other Business-Related services. Only 21 respondents were considered for this question after Data Cleaning. The graphs below show, for each of the items in each sub-category, the percentage of respondents who rated the item as often/very often (a rating of 4 or 5 on the 5 -point scale). The items are presented in order of decreasing rating. The Services were broken down into the following areas:

Administrative Services: Lease of equipment, office space, shared office/administration offices, R\&D facilities, secretarial staff, seminar/conference rooms.

Financial Services: Finance and Bookkeeping services, secretarial staff, legal service.

Other business-related services: Consulting/coaching services, leadership training and coaching, entrepreneurial training, business plan development and support, project management.

HR services: HR Management and sub-contracting services.

IT services: internet, web, computing, and copier services were required by the majority of respondents.

Strategic marketing services: Networking, market research, customer analysis, competitor analysis, stakeholder analysis, macroenvironmental analysis. 
Next, composite scores at respondent level were created for each sub-section by averaging the responses for the items in that sub-section. The univariate statistics for the composite scores are given.

Tab. 4 - Median Scores of Composite Variables for Business Support Services. Source: authors.

\begin{tabular}{|c|c|c|c|c|c|c|c|c|}
\hline Variable & $\mathrm{N}$ & Mean & Std Dev & Median & \multicolumn{2}{|c|}{ IQR } & Min & Max \\
\hline Other bus-related services & 21 & 4.3 & 0.7 & 4.4 & 3.8 & 5.0 & 3.0 & 5.0 \\
\hline Strategic Mkting services & 21 & 3.4 & 1.0 & 3.7 & 2.8 & 4.2 & 1.7 & 5.0 \\
\hline Financial services & 21 & 3.3 & 1.1 & 3.0 & 2.3 & 4.0 & 1.5 & 5.0 \\
\hline HR services & 20 & 2.9 & 1.1 & 3.0 & 2.0 & 3.8 & 1.0 & 5.0 \\
\hline Administrative services & 21 & 3.0 & 1.0 & 2.8 & 2.5 & 4.0 & 1.3 & 4.7 \\
\hline IT services & 20 & 3.0 & 1.1 & 2.8 & 2.2 & 4.0 & 1.3 & 5.0 \\
\hline
\end{tabular}

HR and IT Servies $n=20$

The graph below shows the median score for each sub-section. The highest scores were for Other business-related services (4.4) and Strategic Marketing services (3.7).

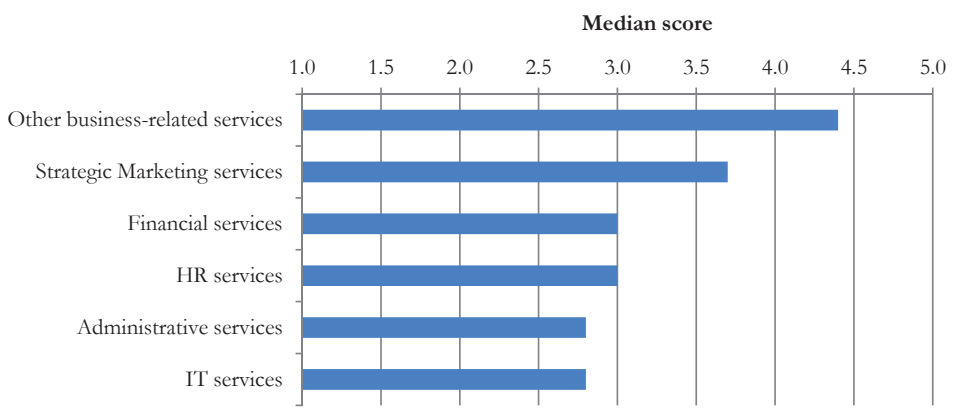

Fig. 7 - Business Incubator Business Support Services to Incubatees (composite scores). Source: authors.

Reviewing the compilation of the top two sections, the 'other business-related services' included: consulting/coaching services, leadership training, business plan development and support and project management - important components of Business strategy. There is a distinct difference between the median of the top two and the rest sub-sections.

"Strategic Marketing services" included networking, market research, customer analysis, competitor analysis, stakeholder analysis and macro environmental analysis. Importantly, these are key components of strategic marketing and are critical 'need to have' experience in running a Business Incubator, it is ongoing information gathering and cannot be overlooked.

Further investigation was required in this area as it was critical to analyse the business support service needs required for the incubatees as if this was not attended to, the entire Business Incubator would struggle and not be sustainable. Therefore, a distinct degree-related qualified and work-experienced respondent would be expected to rate marketing and business-related services 
higher in their quest to make their incubators successful and sustainable. In a Wilcoxon rank sum test, the following two theories were raised:

(1) BI Managers qualifications has an impact on the ranking of Business Support Services needed by the incubatees.

For this, the following hypothesis was selected:

Ho: BI Managers with Business/Marketing qualifications DO NOT RANK 'other businessrelated services' significantly different than those with other degreed qualifications.

H1: BI Managers with Business/Marketing qualifications DO RANK 'other business-related services' significantly different than those with other degreed qualifications.

The median 'Other business-related services' score for those with a Business/marketing qualification (3.8; IQR 3.4-4.6) was not significantly different to the median score for those without such a qualification (4.6; IQR 4.1-5.0) (Wilcoxon rank sum test; $\mathrm{p}=0.18$ ). In this case, the p-value was outside the 0.05 -significance level. Therefore, the null hypothesis was accepted.

A similar test was run to try to prove that:

Ho: BI Managers with Business/Marketing qualifications DO NOT RANK 'strategic marketing services' significantly different than those with other degreed qualifications.

H1: BI Managers with Business/Marketing qualifications DO RANK 'strategic marketing services' significantly different than those with other degreed qualifications.

The median 'Strategic marketing services' score for those with a Business/marketing qualification (4.0; IQR 3.7-4.2) was not significantly different to the median score for those with other degreed qualifications (3.2; IQR 2.7-4.1) (Wilcoxon rank sum test; $\mathrm{p}=0.43$ ). This is classed as an extreme value outside the 0.05 -significance level so again the null hypothesis was accepted.

(2) The BI Managers work experience has an impact on the ranking of the Business Support Services needed by the incubatees.

It was asked of the BI Managers the length of time of work experience they had in their position as head of the 'organisation'. It is observed that overall, $55 \%$ of the respondents had more than 5 years' work experience in that position. It would, therefore, be expected that the more experienced respondents (BI Managers) would value these sub-sets differently than the less experienced managers. The hypothesis test was run accordingly:

Ho: BI Managers with more than 5 years' experience in that position DO NOT RANK 'other business-related services' significantly different than those with less experience.

H1: BI Managers with more than 5 years' experience in that position DO RANK 'other business-related services' significantly different than those with less experience.

The median 'Other business-related services' score for those with more than 5 years' experience (Q4) (4.2; IQR 3.8-4.8) was not significantly different to the median score for those with less experience (4.8; IQR 3.6-5.0) (Wilcoxon rank sum test; $\mathrm{p}=0.30$ ). with a $\mathrm{p}$-value of 
0.30 , this was obtained outside the critical value of 0.05 therefore the null hypothesis was accepted.

In a similar fashion, a Wilcoxon rank sum test was run:

Ho: BI Managers with more than 5 years' experience in this position DO NOT RANK 'strategic marketing services' significantly different than those with less experience.

H1: BI Managers with more than 5 years' experience in this position DO RANK 'other strategic marketing services’ significantly different than those with less experience.

The median 'Strategic marketing services' score for those with more than 5 years' experience (Q4) (3.7; IQR 2.6-4.2) was not significantly different to the median score for those with less experience (3.6; IQR 2.8-4.2) (Wilcoxon rank sum test; $\mathrm{p}=0.97$ ). Again, the null hypothesis was accepted as it fell outside the significance level of 0.05 .

Tab. 5 - BI Managers Qualification and Work Experience scores for Business Support Services. Source: authors

\begin{tabular}{|c|c|c|c|c|c|c|c|c|c|c|}
\hline & $\begin{array}{l}\mathrm{N} \\
\mathrm{Obs}\end{array}$ & $\mathrm{N}$ & Mean & Std Dev & Median & $\mathrm{IQR}$ & & Min & Max & $\begin{array}{l}\mathrm{p} \text {-value } \\
\text { for be- } \\
\text { tween- } \\
\text { group } \\
\text { test }\end{array}$ \\
\hline $\begin{array}{l}\text { Bus_Mktg_- } \\
\text { Qual }\end{array}$ & \multicolumn{10}{|c|}{ Score: Other business-related services } \\
\hline No & 17 & 16 & 4.4 & 0.7 & 4.6 & 4.1 & 5.0 & 3.0 & 5.0 & \multirow{2}{*}{0.18} \\
\hline Yes & 5 & 5 & 4.0 & 0.6 & 3.8 & 3.4 & 4.6 & 3.4 & 4.6 & \\
\hline $\begin{array}{l}\text { Bus_Mktg_- } \\
\text { Qual }\end{array}$ & \multicolumn{10}{|c|}{ Score: Strategic Marketing Services } \\
\hline No & 17 & 16 & 3.3 & 1.1 & 3.2 & 2.7 & 4.1 & 1.7 & 5.0 & \multirow{2}{*}{0.43} \\
\hline Yes & 5 & 5 & 3.8 & 0.9 & 4.0 & 3.7 & 4.2 & 2.3 & 4.7 & \\
\hline $\begin{array}{l}\text { exp_more_- } \\
\text { than_5y }\end{array}$ & \multicolumn{10}{|c|}{ Score: Other business-related services } \\
\hline No & 10 & 10 & 4.4 & 0.8 & 4.8 & 3.6 & 5.0 & 3.0 & 5.0 & \multirow{2}{*}{0.30} \\
\hline Yes & 12 & 11 & 4.2 & 0.6 & 4.2 & 3.8 & 4.8 & 3.2 & 5.0 & \\
\hline $\begin{array}{l}\text { Exp_more } \\
\text { than_5y }\end{array}$ & \multicolumn{10}{|c|}{ Score: Strategic Marketing Services } \\
\hline No & 10 & 10 & 3.4 & 1.0 & 3.6 & 2.8 & 4.2 & 1.7 & 4.7 & \multirow{2}{*}{0.97} \\
\hline Yes & 12 & 11 & 3.4 & 1.1 & 3.7 & 2.6 & 4.2 & $\begin{array}{l}1.7 \\
\end{array}$ & 5.0 & \\
\hline
\end{tabular}


In conclusion, the Ho was accepted on all fronts and confirms that regardless of years of work experience and/or qualifications, there is no significant difference in the way in which respondents ranked 'Other Business-related services' and 'strategic marketing services' as important to the needs of the incubatees. This disproves the theory that strategic marketing concepts are appreciated and understood by suitably qualified and work-experienced BIMs.

Pertaining to inferences in the survey, respondents were asked to rate the skills required as the BI Manager to meet the objective (success) of the Incubator. Respondents showed that even though they wanted to sustain and grow their Business Incubators, they didn't see 'Entrepreneur or Venture Creation specialist' or 'all marketing skills' as an important part of their portfolio of skills set.

(3). 'The BI Managers work experience has an impact on the ranking of the marketing vs nonmarketing scores required by BI Managers.

The hypothesis test was run:

Ho: BI Managers with more than 5 years' experience in this position DO NOT RANK Marketing significantly different than those with less experience.

H1: BI Managers with more than 5 years' experience in this position DO RANK 'Marketing' significantly different than those with less experience.

From the Wilcoxon rank sum test run produced the median Marketing score for those with more than 5 years' experience (Q4) (5.6; IQR 5.3-6.2) was not significantly different to the median score for those with less experience (5.6; IQR 4.8-6.0) (Wilcoxon rank sum test; $\mathrm{p}=0.72)$. Therefore, the null hypothesis was accepted.

Again, we tested the hypothesis the various non-marketing scores:

Ho: BI Managers with more than 5 years' experience in this position DO NOT RANK 'nonMarketing scores' significantly different than those with less experience.

H1: BI Managers with more than 5 years' experience in this position DO RANK 'non-Marketing' significantly different than those with less experience.

The median Non-marketing score for those with more than 5 years' experience (Q4) (5.7; IQR 5.0-6.2) was not significantly different to the median score for those with less experience (6.2; IQR 5.6-6.4) (Wilcoxon rank sum test; $\mathrm{p}=0.18$ ). See Table 6 below:

Tab. 6 - BI Managers work experience Marketing and non-Marketing scores compared. Source: authors.

\begin{tabular}{|l|l|l|l|l|l|l|l|l|l|l|}
\hline \multicolumn{2}{|l|}{ Marketing score } \\
\hline $\begin{array}{l}\text { exp_more_ } \\
\text { than_5y }\end{array}$ & $\begin{array}{l}\text { N } \\
\text { Obs }\end{array}$ & N & Mean & $\begin{array}{l}\text { Std } \\
\text { Dev }\end{array}$ & Median & IQR & Min & Max & $\begin{array}{l}\text { p-value } \\
\text { for be- } \\
\text { tween- } \\
\text { group test }\end{array}$ \\
\hline $\mathrm{n}$ & 10 & 10 & 5.5 & 0.9 & 5.6 & 4.8 & 6.0 & 4.0 & 7.0 & 0.72 \\
\hline $\mathrm{y}$ & 12 & 12 & 5.7 & 0.7 & 5.6 & 5.3 & 6.2 & 4.2 & 6.6 & \\
\hline
\end{tabular}




\begin{tabular}{|l|l|l|l|l|l|l|l|l|l|l|}
\hline \multicolumn{2}{|l|}{ Non-marketing score } \\
\hline $\begin{array}{l}\text { exp_more_ } \\
\text { than_5y }\end{array}$ & $\begin{array}{l}\text { N } \\
\text { Obs }\end{array}$ & N & Mean & $\begin{array}{l}\text { Std } \\
\text { Dev }\end{array}$ & Median & IQR & Min & Max & $\begin{array}{l}\text { p-value } \\
\text { for be- } \\
\text { tween- } \\
\text { group test }\end{array}$ \\
\hline $\mathrm{n}$ & 10 & 10 & 6.1 & 0.5 & 6.2 & 5.6 & 6.4 & 5.2 & 6.8 & 0.18 \\
\hline $\mathrm{y}$ & 12 & 12 & 5.7 & 0.8 & 5.7 & 5.0 & 6.2 & 4.2 & 7.0 & 0.18 \\
\hline
\end{tabular}

Accepting the null hypothesis (Ho), it proves again that most of the respondents (those with 5 or more years' experience), do not rate the marketing skills required more highly than the non-marketing skills and in fact, perceive some critical skills as 'below par'. Again, the BI Managers don't rate the marketing skills highly or higher than non-marketing skills and therefore the incubate and incubator both miss out of those critical skills to grow the business.

From a more inferential statistical perspective, this required the BI Manager to perceive the Business Development Officer (BDO)/Marketing Manager skills to meet the objectives (success) of the Business Incubator. It is expected that experienced BI Managers would rank 'marketing' scores much higher than 'non-marketing' scores in respect skills required for the BDO's. The question raised is:

(4) 'The BI Managers work experience has an impact on the ranking of the marketing vs nonmarketing scores required by BDO/Marketing Manager.

The hypothesis test was run:

Ho: BI Managers with more than 5 years' experience in that position DO NOT RANK 'BDO/Marketing Manager scores' significantly different than those with less experience.

H1: BI Managers with more than 5 years' experience in that position DO RANK 'BDO/ Marketing Manager 'non-Marketing scores' significantly different than those with less experience.

Again, from the composite scores of 'marketing' and 'non-marketing' values using Wilcoxon rank sum test, it was observed that there was no significant difference between both sets of values:

Tab. 7 - Experienced BI Managers perception of BDO/Marketing Manager scores compared. Source: authors.

\begin{tabular}{|c|c|c|c|c|c|c|c|c|c|c|}
\hline \multicolumn{11}{|c|}{ Marketing score } \\
\hline $\begin{array}{l}\text { Q4_exp_- } \\
\text { more_than_ } \\
5 y\end{array}$ & $\begin{array}{l}\mathrm{N} \\
\mathrm{Obs}\end{array}$ & $\mathrm{N}$ & Mean & Std Dev & Median & \multicolumn{2}{|c|}{ IQR } & Min & Max & $\begin{array}{l}\mathrm{p} \text {-value } \\
\text { for be- } \\
\text { tween- } \\
\text { group } \\
\text { test }\end{array}$ \\
\hline $\mathrm{n}$ & 10 & 10 & 5.9 & 0.6 & 6.0 & 5.2 & 6.6 & 5.2 & 6.6 & \multirow{2}{*}{0.92} \\
\hline $\mathrm{y}$ & 12 & 12 & 6.0 & 0.7 & 5.9 & 5.6 & 6.5 & 4.8 & 7.0 & \\
\hline
\end{tabular}




\begin{tabular}{|c|c|c|c|c|c|c|c|c|c|c|}
\hline \multicolumn{11}{|c|}{ Non-marketing score } \\
\hline $\begin{array}{l}\text { Q4_exp_ } \\
\text { more_than_ }\end{array}$ & $\begin{array}{l}\mathrm{N} \\
\text { Obs }\end{array}$ & $\mathrm{N}$ & Mean & Std Dev & Median & \multicolumn{2}{|c|}{ IQR } & \multirow{2}{*}{$\begin{array}{l}\text { Min } \\
4.4\end{array}$} & \multirow{2}{*}{$\begin{array}{l}\text { Max } \\
6.8\end{array}$} & $\begin{array}{l}\mathrm{p} \text {-value } \\
\text { for be- } \\
\text { tween- }\end{array}$ \\
\hline $\mathrm{n}$ & 10 & 10 & 5.8 & 0.7 & 5.9 & 5.4 & 6.4 & & & \multirow{2}{*}{0.62} \\
\hline $\mathrm{y}$ & 12 & 12 & 6.0 & 0.7 & 6.0 & 5.7 & 6.4 & 4.6 & 7.0 & \\
\hline
\end{tabular}

The median Marketing score for those with more than 5 years' experience (5.9; IQR 5.6-6.6) was not significantly different to the median score for those with less experience (6.0; IQR 5.2-6.6) (Wilcoxon rank sum test; $\mathrm{p}=0.92$ ).

The median Non-marketing score for those with more than 5 years' experience (6.0; IQR 5.7 -6.4) was not significantly different to the median score for those with less experience (5.9; IQR 5.4-6.4) (Wilcoxon rank sum test; $\mathrm{p}=0.62$ ).

Again, the null hypothesis was accepted and the conclusion drawn is that years of work experience did not have a significant impact on how the respondents ranked marketing and nonmarketing skills required by the BDO's. It can be further concluded that the BI Manager does not differentiate much between the marketing and non-marketing skills required by the BDO. It was however indicated in Figure 3 that 'great grasp of BD and Marketing' was highly rated, 'identify and attract customers' and 'ID of customers and potential customers' were important. It could be viewed that from the responses, a more sales focused approach was expected from the BI Manager. Therefore, it is important to realise that the BI Manager requires some education around strategic marketing and the value that would bring to the business incubator success.

Reviewing the comparison between the skills set of the BIM and those perceived for the BDO/ Marketing Manager, the scatterplot showed a positive and significant correlation indicating that both positions should have significant strategic marketing experience to grow their incubators. In this regard, work experience had no real impact of the perception of both roles and so the need for strategic marketing is critical.

The BIM must be aware of the industry dynamics that he/she is involved in along with a total understanding of how many incubatees the organisation can sustain and at what stage these incubatees are at during their tenure and their status with product and market development. This is critical for the survival and sustainability of the incubator. Furthermore, it is essential for the BIM to have a strategic marketing plan to be able to keep focused on a vision to grow the Business Incubator. If this does not happen, the BI may lose funding and possible relationships.

Integrated Marketing Communications plans require to be part of the marketing and business strategy through business intelligence is necessary so that this information can be divulged to all key management personnel. Continuous review is important so that BIMs can manage their incubatees accordingly. 


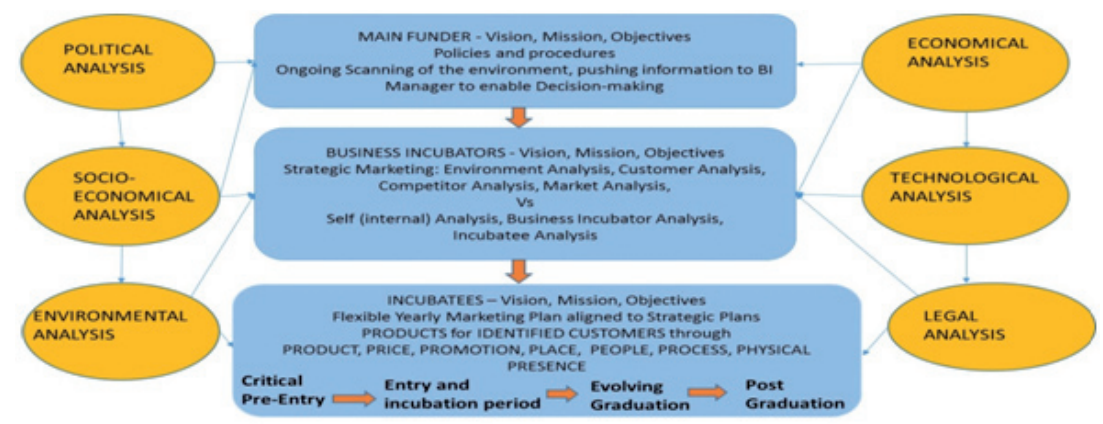

Fig. 8 - Strategic Marketing snapshot for Business Incubators. Source: authors.

The researcher is not aware of any such survey being performed previously and would therefore say that this could be classed as the first of its kind in South Africa. Other similar surveys can now be performed for further segmentation and analysis. The researcher has therefore designed the model in Figure 8 which should enable future readers and respondents to identify a 'global' picture of Strategic Marketing. This should enable Business Incubator Management and staff to get an all-round perception of driving strategic marketing forward in their organisations.

\section{CONCLUSIONS}

Overall, whilst the survey was aimed at a small, focused group of Business Incubators from the largest program of Public Sector segment in South Africa, strategic marketing, in its true, recognisable form, is not seen as a key differentiator in the success of business incubators in this sector of the South African economy. BI Managers did not rank Marketing values and non-Marketing values significantly different. One conclusion that can be drawn from these analyses is that the respondents did not fully understand Strategic Marketing and may be confusing these principles with the sales or other metrics that may temporarily raise employment statistics.

It can be seen from the survey that many of the incubatees selected did not fit the criteria for entry as they required a lot of business support which, evidently the Business Incubators and management could not provide, especially in the business and strategic marketing areas.

It was also revealing that stakeholder management was a key issue and was poorly organised with the lack of CRM systems, identification and ongoing collusion of universities and technical colleagues. Many of these institutions are the cornerstone of innovation and creativity and play an important $\operatorname{cog}$ in the wheel of entrepreneurship, start-ups and business incubation in many developing countries.

The fact that several of the Business Incubator websites $(23 \%)$ were not functional or inaccessible at the time of the survey is of concern. To market the Business Incubators and give various stakeholders the opportunity to view their strategic intent, business objectives and value proposition, it is imperative to have a functioning website with several pages about the Incubator; where it is, what it does, on a digital platform operating with connections to a Facebook 
page and/or possibly a twitter account. We are now in a digital age where customers' opinions really matter and impact on the way we communicate and keep customers happy. Additionally, branding the incubator with other local community or brand names is the key to developing and entrenching recognition.

\section{References}

1. Akcomak, I. S. (2009). Incubators as Tools for Entrepreneurship Promotion in Developing Countries. Netherlands: UNU-MERIT Working Papers.

2. Al-Mubaraki, H. M., \& Busler, M. (2010). Business incubators findings from a worldwide survey, and guidance for the GCC states. Global Business Review, 11(1), 1-20.

3. Al-Mubaraki, H., \& Busler, M. (2011a). Application of Business Incubators in Europe: A SWOT Analysis, WASD 9th International Conference. Atlantic City, U.S.A. October 26$28,2011$.

4. Al-Mubaraki, H., \& Busler, M. (2011b). The development of entrepreneurial companies through business incubator programs. International Journal of Emerging Sciences, 1(2), 95-107.

5. Al-Mubaraki, H. M., \& Busler, M. (2012). Innovation systems in European countries: a SWOT analysis. European Journal of Business and management, 4(15).

6. Anderson, B. B., \& Al-Mubaraki, H. (2012). The Gateway Innovation Center: exploring key elements of developing a business incubator. World Journal of Entrepreneurship, Management and Sustainable Development, 8(4), 208-216.

7. Androniceanu, A. (2017). The Three-Dimensional Approach of Total Quality Management, an Essential Strategic Option for Business Excellence. Amfiteatru Economic, 19(44), 61-78.

8. Androniceanu, A., Ohanyan, G.(2016). Comparative approach on education and healthcare in Romania and Bulgaria as beneficiaries of the IMF financial assistance. Administratie si Management Public, 2016 (26), 25-48.

9. Bayhan, A. (2001). Business incubator process: a toll for entrepreneurship and enterprise development in a knowledge-based economy. Competitive Support fund.

10. Belás, J., Ključnikov, A., Vojtovič, S., \& Sobeková-Májková, M. (2015). Approach of the SME Entrepreneurs to Financial Risk Management in Relation to Gender and Level of Education. Economics and Sociology, 8(4), 32-42. https://doi.org/10.14254/2071-789X.2015/8$4 / 2$.

11. Bruneel, J., Ratinho, T., Clarysse, B., \& Groen, A. (2012). The Evolution of Business Incubators: Comparing demand and supply of business incubation services across different incubator generations. Technovation, 32(2), 110-121.

12. Dobeš, K., Kot, S., Kramoliš, J., \& Sopková, G. (2017). The Perception of Governmental Support in The Context of Competitiveness of SMEs in the Czech Republic. Journal of Competitiveness, 9 (3), 34-50. https://doi.org/10.7441/joc.2017.03.03.

13. Chan, K. F., \& Lau, T. (2005). Assessing technology incubator programs in the science park: the good, the bad and the ugly. Technovation. 25(10), 1215-1228. 
14. Chandra, A. (2009). Business Incubation in Brazil: Creating an Environment for Ventures. Enterprise Development and Microfinances, 20 (1), 27-44.

15. Du Toit, A. S. A., \& Sewdass, N. (2014). A comparison of competitive intelligence activities in Brazil, Malaysia, Morocco and South Africa. Acta Commercii 14(1), Art. \#234, 7 pages. http://dx.doi. org/10.4102/ac. v14i1.234.

16. Fini, R., Grimaldi, R., Marzocchi, G. L., \& Sobrero, M. (2012). The determinants of corporate entrepreneurial intention within small and newly established firms. Entrepreneurship Theory and Practice, 36(2), 387-414.

17. Global Entrepreneurship Monitor (2010). South Africa Report, Cape Town: GEM.

18. Grimaldi, R., \& Grandi, A. (2005). Business incubators and new venture creation: an assessment of incubating models. Technovation, 25(2), 111-121.

19. InfoDev (2009). Business Incubators [Online] Available: http://www.idisc.net/WorkGroups/ index.html.

20. InfoDev (2010c). Global Practice in Incubation: Policy Development and Implementation. Brazilian Incubation Case Study. Washington DC: The World Bank.

21. Ključnikov, A., Belás, J., Kozubíková, L., \& Paseková, P. (2016). The Entreprenurial Perception of SME Business Environment Quality in the Czech Republic. Journal of Competitiveness, 8 (1), 66-78. https://doi.org/10.7441/joc.2016.01.05.

22. Kosiova, E, Habanik, J., Virglerova, Z., \& Rozsa, Z. (2017). SMEs Financing as an Important Factor of Business Environment in Slovak Republic Regions. Montenegrin Journal of Economics, 13 (2), 129-140. 10.14254/1800-5845/2017.13-2.8.

23. Kot, S., Meyer, N., \& Broniszewska, A. (2016). A Cross-Country Comparison of the Characteristics of Polish and South African Women Entrepreneurs. Economics and Sociology, 9(4), 207-221. https://doi.org/10.14254/2071-789X.2016/9-4/13.

24. Kozubíková, L., Homolka, L., \& Kristalas, D. (2017). The Effect of Business Environment and Entrepreneurs' Gender on Perception of Financial Risk in The Smes Sector. Journal of Competitiveness, 9(1), 36-50. https://doi.org/10.7441/joc.2017.01.03.

25. Lauzikas, M., Miliute, A., Bilota, A., \& Bielousovaite, D. (2017). Main development drivers of start-up companies within start-up ecosystems: The case of Lithuania. Marketing and Management of Innovations, 2(1), 316-328.

26. Lai, W. H. and Lin, C. C. (2015). Constructing business incubation service capabilities for tenants at post-entrepreneurial phase. Journal of Business Research, 68(11), 2285-2289.

27. Lalkaka, R., \& Bishop, J. (1996). Business Incubators in Economic Development: an initial assessment in industrializing countries. United Nations Development Programme, New York, Organisation of American States, Washington DC, United Nations Industrial Development Organisation, Vienna.

28. Liedholm, C. E., \& Mead, D. C. (2013). Small enterprises and economic development: the dynamics of micro and small enterprises. Routledge. 
29. Masutha, M. (2013). Small Business Incubators in South Africa: Emergence, Geography and Local Impacts. University of Johannesburg. Unpublished MSc Dissertation. Submitted: October 2013. Retrieved October 6, 2015 from: [Online] https://ujdigispace.uk.ac.za.

30. Mishenina, N. V., Yarova, I. Y., \& Mishenina, H. A. (2017). Development of mechanisms of public-private partnership in the sphere of nature management in conditions of decentralization. Marketing and Management of Innovations, 8 (1), 319-330.

31. Salem, M.I. (2014). The role of business incubators in the economic development of Saudi Arabia. The International Business \& Economics Research Journal (Online), 13(4), 853-859.

32. Sandheep, R., \& Wolfgang, T. (2011). How are South Africa's Government-subsidised small business incubators doing at nurturing start-up enterprises? Raising Business Agenda 2, 18-21.

33. Timm, S. (2012). How the state and private sector can partner to boost support to SMEs: Lessons from Chile \& Malaysia. Report for the Department of Trade and Industry and TIPS. Pretoria.

34. Waheeduzzaman, A. N. M. (2002). Competitiveness, human development and inequality: A cross-national comparative inquiry. Competitiveness Review: An International Business Journal, 12(2), 13-29.

\section{Contact information}

Donaldson Walter James, Ph.D.

University of America, California, USA

Faculty of Business Management

E-mail:walterdonaldson@gmail.com

Pauceanu Alexandrina Maria, Ph.D

Higher Colleges of Technology, UAE

Faculty of Business Division

Email:apauceanu@hct.ac.ae 